\title{
Properties of a Lactobacillus fermenti bacteriocin
}

\author{
By H. C. DE KLERK \\ Department of Microbiology, University of Pretoria, Pretoria, South Africa \\ AND J. A. SMIT \\ Division of Life Sciences, Atomic Energy Board, Pretoria, South Africa
}

(Accepted for publication 22 March 1967)

\begin{abstract}
SUMMARY
The properties of a bacteriocin derived from Lactobacillus fermenti strain 466 were investigated. The bacteriocin was present in low titre in supernatant fluids from overnight broth cultures and was not inducible by ultraviolet radiation. It was purified and concentrated to a titre of $1 / 1000$ by dialysis, chromatography on Sephadex G IOO and calcium phosphate gel columns. The bacteriocin is heat stable, and sensitive to trypsin and pepsin but not to lysozyme. No migration was demonstrated in electrophoretic fields in agar gel. Electron microscopy of the bacteriocin did not show any phage components. The bacteriocin is a macromolecular lipocarbohydrate protein which consists of 16 amino acids, four sugars, hexosamine and phosphorus. The biological activity of this complex is dependent on its structural integrity.
\end{abstract}

\section{INTRODUCTION}

Bacteriocins as defined by Reeves (1965) are produced by homofermentative and heterofermentative species of the genus Lactobacillus (de Klerk \& Coetzee, 196I). The incidence of bacteriocinogeny in Lactobacillus fermenti is $15.5 \%$ (de Klerk, 1967). All the $L$. fermenti bacteriocins have an identical host range and attempts to isolate resistant mutants have been unsuccessful. This has precluded the classification of these bacteriocins by cross-resistance tests (Fredericq, 1948). Colicins K (Goebel \& Barry, 1958), V (Hutton \& Goebel, I96I, 1962), F ( $\left.E_{2}\right)$ (Reeves, 1963), A (Barry, Everhart, Abbot \& Graham, 1965), I (Keene, 1966) and the unclassified colicin SG 710 (Nüske, Hösel, Venner \& Zinner, 1957) are complexes of lipid, carbohydrate and protein. Megacin 216 (Holland, I96I) and a pyocin (Homma \& Suzuki, 1964) are proteins. The specific chemical nature of all other bacteriocins is unknown (Hinsdill \& Goebel, 1964; Reeves, 1965). The purpose of the present investigation was the purification and chemical analysis of one of the apparently homogeneous group of $L$. fermenti bacteriocins.

\section{METHODS}

Media. The liquid medium used was the MRS broth of de Man, Rogosa \& Sharpe (I960) freed from high molecular weight constituents by dialysis (tubing size $18 / 32$, Visking Co., Chicago, Ill., U.S.A.) under negative pressure. Solid medium was MRS broth diffusate $+2 \%(w / v)$ agar.

Bacterial strains. The bacteriocinogenic Lactobacillus fermenti strain 466 , the indicator $L$. fermenti strain F I and other indicator strains were described by de Klerk $\&$ Coetzee (196I). Cultures were incubated as previously described (de Klerk, I967). 
Preparation of bacteriocin. Crude preparations of bacteriocin were obtained by overnight growth of the bacteriocinogenic strain at $37^{\circ}$ in broth diffusate medium. The culture was centrifuged, the supernatant fluid sterilized with chloroform and concentrated in a rotary evaporator at $40^{\circ}$. The concentrate was dialysed against deionized water to remove nutrients and small molecular weight bacterial products in the diffusate. The volume of the dialysis residue was further decreased by evaporation and then dialysed against $0 . \mathrm{I} \mathrm{M}-\mathrm{KCl}+0.05 \mathrm{M}$-tris $+\mathrm{HCl}$ buffer $(\mathrm{pH} 7.5)$.

Purification of bacteriocin. Crude bacteriocin was purified by gel filtration on Sephadex G I0o. Samples ( $2 \mathrm{ml}$.) were applied to columns $(50 \mathrm{~cm} . \times 2.5 \mathrm{~cm}$.) and eluted with $0 . \mathrm{I} \mathrm{M}-\mathrm{KCl}+0.05 \mathrm{M}$-tris $+\mathrm{HCl}$ buffer ( $\mathrm{pH} \mathrm{7.5).} \mathrm{Column} \mathrm{effluents} \mathrm{were} \mathrm{collected} \mathrm{in} 5 \mathrm{ml}$. fractions and assayed for activity and the extinction at $280 \mathrm{~m} \mu$ determined. High titre fractions were pooled and centrifuged at $200,000 \mathrm{~g}$ for $\mathrm{I} 5 \mathrm{~min}$. to remove bacterial debris. The supernatant fluid concentrated, dialysed against buffer and the dialysis. residue filtered through Sephadex or chromatographed on calcium phosphate gel columns.

Adsorption chromatography of bacteriocin on calcium phosphate gel. Precipitated calcium phosphate was prepared according to Tiselius, Hjertén \& Levin (1956), suspended in I mM-sodium phosphate buffer (pH 6.8) and applied to a chromatography tube $(0.8 \mathrm{~cm}$. $\times 12 \mathrm{~cm}$.). A sample $(2 \mathrm{ml}$. equiv., Io mg. dry wt) of partly purified bacteriocin was dialysed against I mM-sodium phosphate $(\mathrm{pH} 6.8)$ and applied to the column. The bacteriocin was eluted with I mM-sodium phosphate buffer (pH 6.8) and step-wise elution with 10, 50 and 200 mM-sodium phosphate buffer solutions (pH 6.8; $50 \mathrm{ml}$. of each concentration) was continued. Fractions $(5 \mathrm{ml}$.) were collected and assayed for activity and the extinction at $280 \mathrm{~m} \mu$ determined.

Ultraviolet induction of bacteriocin. Lactobacillus fermenti strain 466 organisms. from a $20 \mathrm{ml}$. overnight broth culture were deposited by centrifugation and resuspended in an equal volume of sterile distilled water in a Petri dish. The suspension was irradiated with a $30 \mathrm{~W}$. Hanovia Sterilamp (wavelength $2537 \AA$ ) from a height of $25 \mathrm{~cm}$. At intervals of 5, 10, 15, 25, $40 \mathrm{sec}$., samples of $4 \mathrm{ml}$. were pipetted into $20 \mathrm{ml}$. warmed broth and incubated overnight in the dark. The supernatant fluids of these cultures were sterilized with chloroform and assayed for bacteriocin activity.

Assay of the bacteriocin. This was done by spotting drops of two-fold serial dilutions of the material in MRS broth on to agar plates seeded with the indicator strain and incubated overnight at $37^{\circ}$. The highest inhibitory dilution was the titre.

\section{Analysis of bacteriocin}

Purified bacteriocin was dialysed against repeated changes of distilled water and evaporated to constant dry weight under reduced pressure over $\mathrm{P}_{2} \mathrm{O}_{5}$. The bacteriocin $(84.1 \mathrm{mg}$.) was then dissolved in distilled water $(25 \mathrm{ml}$.).

Samples $(0.2 \mathrm{ml}$.) of bacteriocin preparation were treated with $3 \mathrm{~N}-\mathrm{NaOH}(0.1 \mathrm{ml}$.) and the protein content measured by the method of Lowry, Rosebrough, Farr \& Randall (I95I), with crystalline bovine albumin (Armour Pharmaceutical Co., Kankakee, Ill., U.S.A.) as standard.

Total nitrogen was determined by a micro-Kjeldahl technique (Ballantine, 1957).

Deoxyribonucleic acid (DNA) and ribonucleic acid (RNA) were determined by the methods of Burton (1956) and Dische \& Borenfreund (1957), respectively.

Bacteriocin $(6 \cdot 728 \mathrm{mg}$.) was hydrolysed in a sealed tube for $24 \mathrm{hr}$ with $6 \mathrm{~N}-\mathrm{HCl}$ 
(5 ml.) at $105^{\circ}$. The acid was evaporated in vacuo over solid $\mathrm{P}_{2} \mathrm{O}_{5}$ and $\mathrm{NaOH}$, and the amino acid composition determined with a Beckman automatic amino acid analyser, Model I2OB.

Bacteriocin ( $3 \mathrm{ml}$.) was treated with $12 \mathrm{~N}$-perchloric acid $\left(0.36 \mathrm{ml}\right.$.) and left at $0^{\circ}$ for $\mathrm{I} 6 \mathrm{hr}$. The precipitated protein was removed by centrifugation and total phosphate in the supernatant fluid estimated by the method of Gomori (1942).

Estimation of lipids. The total lipid content of bacteriocin solution (Io ml.) was determined according to Salton (1953). The procedure consisted of hydrolysis with $6 \mathrm{~N}-\mathrm{HCl}$ for $8 \mathrm{hr}$ at $100^{\circ}$, followed by ether extraction of the hydrolysate.

Hexosamine estimation. Samples $(2 \mathrm{ml}$.) of bacteriocin solution were hydrolysed in sealed tubes with $4 \mathrm{~N}-\mathrm{HCl}$ for $\mathrm{I} 5 \mathrm{hr}$ at $100^{\circ}$. The acid was evaporated in vacuo over solid $\mathrm{P}_{2} \mathrm{O}_{5}$ and $\mathrm{NaOH}$, and the liberated hexosamine separated from interfering: substances (sugars and lipids) by cation exchange chromatography on columns $\left(\mathrm{I} \mathrm{cm} . \times 10 \mathrm{~cm}\right.$.) of Amberlite IR 120 ( $\mathrm{H}^{+}-$form) resin. The hexosamine was eluted with $2 \mathrm{~N}-\mathrm{HCl}$ and estimated according to Boas (1953), with glucosamine hydrochloride (British Drug Houses Ltd.; BDH) as standard.

Liberation of carbohydrates. The bacteriocin solution $(2 \cdot 0 \mathrm{ml}$.) was hydrolysed for

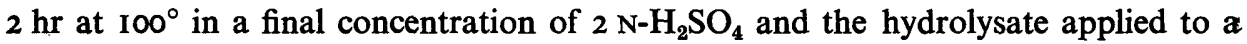
column ( $\mathrm{I} \mathrm{cm} . \times 10 \mathrm{~cm}$.) of Amberlite IR I $20\left(\mathrm{H}^{+}\right.$-form) cation exchange resin (Weibull $\&$ Bergström, 1958). Neutral sugars were eluted with water and concentrated under reduced pressure below $40^{\circ}$ to a small volume. The sugar solution was transferred quantitatively to a $5 \mathrm{ml}$. standard flask and made to volume.

Paper chromatography of carbohydrates. One-dimensional descending chromatography was done on Whatman no. I filter paper with 2,4,6-trimethylpyridine as solvent (Partridge, 1948). D(t)-Galactose, $D(+)$-glucose, $D(+)$-mannose and L(+)-rhamnose (British Drug Houses Ltd.) were used as references. After developing the chromatograms for $40 \mathrm{hr}$, the solvent was removed by evaporation and the chromatograms sprayed with $p$-anisidine phosphate in ethanol (Mukherjee \& Srivastava, 1952).

Quantitative estimation of carbohydrate components. A sample $(0.5 \mathrm{ml}$.) of the sugar extract was applied as a band ( $10 \mathrm{~cm}$. wide) in the centre and $8 \mathrm{~cm}$. from the top of Whatman no. I filter paper $(30 \mathrm{~cm} . \times 57 \mathrm{~cm}$.) together with two guide spots, $5 \mathrm{~cm}$. from each edge, to which $50 \mu \mathrm{l}$. of sugar extract were applied. This chromatogram and a blank were developed for $40 \mathrm{hr}$ in 2,4,6-trimethylpyridine and dried for $16 \mathrm{hr}$ at room temperature. The positions of the separated sugars on the guide strips were revealed by the reagent and the corresponding areas excised from the experimental and blank chromatogram. Sugars and blanks were quantitatively eluted from each strip with distilled water into measuring cylinders $(5 \mathrm{ml}$.) according to Dent (1947). Elution was stopped when $2 \mathrm{ml}$. of solvent had been collected and samples (I ml.) were assayed for sugar concentration by the anthrone method of Scott \& Melvin (1953).

Dissociation of protein and carbohydrate fractions. The phenol method of Goebel \& Barry (1958) and hydrolytic techniques (Knox \& Hall, 1965) were used in attempts to dissociate protein and carbohydrate components of the bacteriocin respectively.

Sedimentation of bacteriocin. This was done at $59780 \mathrm{rev} . / \mathrm{min}$. at $20^{\circ}$ in the AN-D rotor of a Spinco model $\mathrm{E}$ ultra-centrifuge. A solution of about $\mathrm{I} \%$ purified 
bacteriocin was used in a $12 \mathrm{~mm}$. standard cell and photographs were taken at $8 \mathrm{~min}$. intervals, with schlieren optics.

\section{Action of enzymes on bacteriocin}

Lysozyme. Bacteriocin solution $\left(3 \mathrm{mg} . / \mathrm{ml}\right.$.) was incubated at $37^{\circ}$ with an equal volume of lysozyme (BDH; $100 \mu \mathrm{g} . / \mathrm{ml}$.) in $0.1 \mathrm{M}$-ammonium acetate for $5 \mathrm{hr}$.

Pepsin. Bacteriocin solution $\left(3 \mathrm{mg} . / \mathrm{ml}\right.$.) was incubated at $37^{\circ}$ with an equal volume of crystalline pepsin (BDH; $1 \mathrm{mg} . / \mathrm{ml}$.) in $0.02 \mathrm{~N}-\mathrm{HCl}$ for $24 \mathrm{hr}$. After digestion the mixture was adjusted to $\mathrm{pH} 7 \cdot 0$ with $0.1 \mathrm{~N}-\mathrm{NaOH}$.

Trypsin. Bacteriocin solution ( $3 \mathrm{mg} . / \mathrm{ml}$.) was incubated at $37^{\circ}$ with an equal volume of crystalline trypsin (BDH; $0.5 \mathrm{mg}$./ml.) in $200 \mathrm{~mm}$-sodium phosphate buffer (pH 7.5) for $3 \mathrm{hr}$. Control experiments were done without enzymes and bacteriocin titres determined.

\section{Other investigations}

Action of urea on bacteriocin. Bacteriocin was dissolved in a final concentration of $6 \mathrm{M}$-urea. Controls consisted of bacteriocin in water and a $6 \mathrm{M}$-urea solution. After $16 \mathrm{hr}$ at $37^{\circ}$ the solutions were assayed.

Chromatography on ion-exchange resins. This was done on Amberlite IR 410 ( $\mathrm{Cl}$--form) anion and Amberlite IR I2O $\left(\mathrm{H}^{+}\right.$-form) cation exchange resins.

Agar electrophoresis. Agar electrophoresis of purified bacteriocin at $\mathrm{pH} 5 \cdot 2$ and pH 8.5 was done by the method of Maré, Coetzee \& de Klerk (1964).

Electron microscopy. Purified bacteriocin dissolved in distilled water was negatively stained with neutral potassium phosphotungstate (Brenner \& Horne, 1959). Samples were mounted on carbon support films by a spreading technique (Bradley, 1962) and examined with a Philips EM 200 electron microscope.

\section{RESULTS}

\section{Isolation of pure bacteriocin}

Supernatant fluids of overnight cultures of Lactobacillus fermenti strain 466 in the MRS diffusate medium had inhibitory titres of $1 / 4$. This medium did not contain molecules with a weight exceeding 10,000 (Leggett Bailey, 1962) and facilitated the separation of the bacteriocin which was not diffusible through the Visking tubing (de Klerk \& Coetzee, 1961). Bacteriocin production was not enhanced by ultraviolet irradiation. One litre of crude bacteriocin was purified and concentrated to $2 \mathrm{ml}$. with a titre of $\mathrm{I} / 1000$, this represented a recovery of $40-60 \%$. The primary separation of fractions on Sephadex (Fig. I) and further purification on calcium phosphate gel (Fig. 2) are shown. In both graphs two peaks are present. The first had an absorption maximum of $277 \mathrm{~m} \mu$ and contained all the activity. The second peak represented bacterial protein and broth constituents, and was virtually absent after repassage through either column. Ultracentrifugation of the purified bacteriocin revealed a single peak with an $S_{20, w}$ value of $\mathbf{2 \cdot 8}$.

\section{Chemical composition}

The chemical composition of the bacteriocin is shown in Table I. It consisted mainly of carbohydrate, protein and lipid, with lesser amounts of hexosamine and phosphorus, and was free from nucleic acids. The carbohydrate fraction (Table 2) contained four sugars; the mannose content being $56.7 \%$. The protein fraction con- 
tained 16 amino acids (Table 3). Alanine, glycine, serine and the acidic amino acids were present in the highest concentrations.

\section{Properties of the bacteriocin}

Purified bacteriocin was a fluffy, white amorphous powder freely soluble in water. Aqueous solutions kept at room temperature for several days showed no loss of activity and neutral solutions withstood heating at $96^{\circ}$ for $30 \mathrm{~min}$. Activity was completely destroyed by trypsin and was decreased to half when treated with pepsin for $24 \mathrm{hr}$. The bacteriocin was unaffected by lysozyme. Phenol did not split a protein with bacteriocin activity from the complex; this corresponds to the findings of Barry et al. (1965) with colicin A. Attempts to separate the carbohydrate moiety by hydrolysis with hot $0.1 \mathrm{~N}$-sulphuric acid or warm $10 \%(\mathrm{w} / \mathrm{v})$ trichloroacetic acid resulted in total

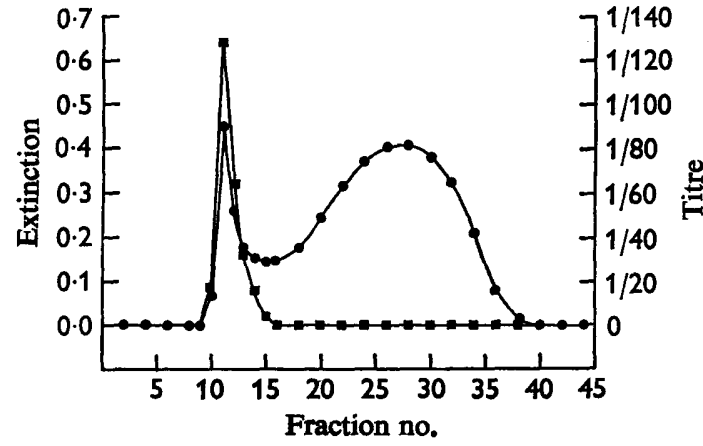

Fig. I

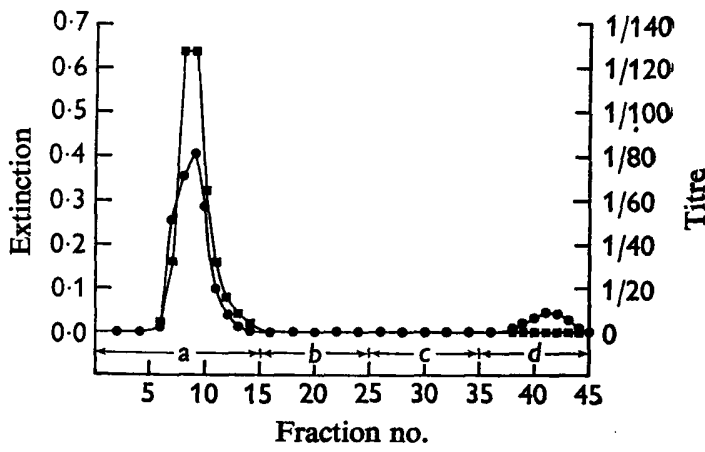

Fig. 2

Fig. I. Chromatography of crude bacteriocin of Lactobacillus fermenti 466 on Sephadex G-100. A $2 \mathrm{ml}$. sample (titre: I/I000) was applied to the column and eluted with $0 \cdot \mathrm{I} \mathrm{M}-\mathrm{KCl}+$ $0.05 \mathrm{M}$-tris $+\mathrm{HCl}$ buffer $(\mathrm{pH} 7 \cdot 5)$. Fractions $(5 \mathrm{ml}$.) were collected and assayed for: extinction; and $\mathrm{a}-\mathrm{a}$, inhibitory activity.

Fig. 2. Chromatography of bacteriocin of Lactobacillus fermenti 466 on calcium phosphate gel. Partially purified bacteriocin was concentrated and dialysed against I mM-sodium phosphate buffer (pH 6.8). A $2 \mathrm{ml}$. sample (titre: 1/1000) was applied to the column and stepwise elution done with sodium phosphate buffer (pH 6.8) at concentrations of $1,10,50$ and $200 \mathrm{mM}$. Fractions $(5 \mathrm{ml}$.) were collected and assayed for: -0 , extinction; and - inhibitory activity. (a) I mM, (b) 10 mM, (c) $50 \mathrm{mM},(d) 200 \mathrm{~mm}$-sodium phosphate.

Table I. Chemical composition of bacteriocin of Lactobacillus fermenti strain 466

(\%)

$\begin{array}{lr}\text { Nitrogen } & 4.96 \\ \text { Protein } & 23 \cdot 80 \\ \text { Lipid } & 20.80\end{array}$

$53 \cdot 20$

$\begin{array}{lr}\text { Carbohydrate } & 53.20 \\ \text { Hexosamine } & 0.80 \\ \text { Phosphorus } & 0.30\end{array}$

Table 2. Carbohydrate composition of bacteriocin of Lactobacillus: fermenti strain 466

(\%)

Galactose

Glucose
$19 \cdot 4$

16.7
$(\%)$

$56 \cdot 7$ 
inactivation. Extraction of a bacteriocin solution with chloroform or ether removed no lipid material and did not affect activity. The bacteriocin activity was also unaffected by treatment with urea. Agar electrophoresis at different $\mathrm{pH}$ values showed no migration of the bacteriocin when several different Lactobacillus fermenti strains were used as indicators. Anion and cation exchange resins did not retain the bacteriocin. Electron microscopic examination showed only amorphous material.

\section{Table 3. Amino acid composition of the protein fraction of bacteriocin of Lactobacillus fermenti strain 466}

$\begin{array}{lclc}\text { Amino acid } & \begin{array}{c}\text { Residues/I000 total amino } \\ \text { acid residues }\end{array} & \begin{array}{c}\text { Amino acid } \\ \text { Lysine }\end{array} & \begin{array}{c}\text { Residues/I000 total amino } \\ \text { acid residues }\end{array} \\ \text { Histidine } & 57 \cdot 3 & \text { Glycine } & 11 \text { I } \cdot 2 \\ \text { Arginine } & 18 \cdot 9 & \text { Alanine } & 134 \cdot 3 \\ \text { Aspartate } & 29 \cdot 0 & \text { Valine } & 56 \cdot 0 \\ \text { Threonine* } & 100 \cdot 1 & \text { Methionine } & 4 \cdot 5 \\ \text { Serine* } & 87 \cdot 6 & \text { Isoleucine } & 37 \cdot 6 \\ \text { Glutamate } & 101 \cdot 0 & \text { Leucine } & 64 \cdot 0 \\ \text { Proline } & 92 \cdot 3 & \text { Tyrosine } & 30 \cdot 7 \\ & 47 \cdot 2 & \text { Phenylalanine } & 28 \cdot 3\end{array}$

\section{DISCUSSION}

Lactobacillus fermenti strain 466 produces a single bacteriocin, which is non-inducible by ultraviolet radiation. The bacteriocin differs in the latter respect from megacin 216 (Holland, 196I), colicin F (Reeves, 1963) and pyocin (Homma \& Suzuki, 1964). It is a lipocarbohydrate protein similar in general composition to colicins (Hinsdill \& Goebel, 1964). Attempts to isolate an active protein fraction from the complex were unsuccessful although the phenol method ruptures covalent bonds (Holland, 196I) and an active protein was split from the colicin $\mathbf{K}$ complex in this way (Goebel \& Barry, 1958). Mild techniques of hydrolysis which split sugar phosphate bonds to release a carbohydrate fraction (Knox \& Hall, 1965) destroyed the biological activity of the bacteriocin. These findings support the conclusion that activity depends on the integrity of the lipocarbohydrate protein complex. The chemical composition of only one of the bacteriocins produced by Gram-positive organisms, megacin 216 (Holland, I96I), is known; this is a protein with traces of phosphorus and carbohydrate. The enterocin of Streptococcus zymogenes (Brock \& Davie, 1963) is possibly a protein (Hamon, 1964) with a lipid component. The 16 amino acids of the Lactobacillus fermenti strain 466 bacteriocin correspond to those of megacin 216 (Holland, 196I), but the concentration of acidic amino acids in the latter bacteriocin is higher. The lactobacillus bacteriocin has a trace of methionine whilst cysteine/cystine are absent. This suggests that the three-dimensional structure of the macromolecule does not depend on the presence of disulphide linkages. The activity of this bacteriocin is probably independent of hydrogen bonds since it is not affected by high concentrations of urea.

The absence of migration in an electric field at different $\mathrm{pH}$ values was unexpected since the dicarboxylic amino acids, aspartate and glutamate, predominate. The bacteriocin diffused through $0.8 \%(w / v)$ agar (de Klerk, 1967) and its electrophoretic immobility did not result from inability to penetrate the agar lattice. The failure of 
ion-exchange resins to retain the bacteriocin confirms its lack of net ionic charge: its ionic groups may be masked by lipid.

Homma \& Suzuki (1964) isolated a cell-wall protein with bacteriocin activity from Pseudomonas aeruginosa. Cell walls of Lactobacillus fermenti contain galactose, glucose, glucosamine and aspartate, glutamate, alanine and lysine (Ikawa \& Snell, 1960). The bacteriocin of $L$. fermenti strain 466 differs in composition from its cell wall and is much more complex.

This work was supported by grants to Professor J. N. Coetzee from the South African Council for Scientific and Industrial Research.

\section{REFERENCES}

Ballantine, R. (1957). Determination of total nitrogen and ammonia. Meth. Enzymol. 3, 984.

Barry, G. T., Everhart, D. L., AbBott, V. \& Graham, M. G. (1965). Preparation, properties and relationship of substances possessing colicine A activity obtained from Enterobacteriaceae. Zentbl. Bakt. (Orig. Abt. I), 196, 248.

Boas, N. F. (1953). Method for the determination of hexosamines in tissues. J. biol. Chem. 204, 553.

BraDley, D. E. (1962). A study of the negative staining process. J. gen. Microbiol. 29, 503.

BrenNer, S. \& HoRNe. R. W. (1959). A negative staining method for high resolution electron microscopy of viruses. Biochim. biophys. Acta 34, 103.

Brock, T. D. \& DAvIE, J. M. (1963). Probable identity of a group D hemolysin with a bacteriocine. J. Bact. 86, 708.

BuRToN, K. (1956). Diphenylamine reaction for the colorimetric estimation of DNA. Biochem. J. 62, 315.

DE KLERK, H. C. (1967). Bacteriocinogeny in Lactobacillus fermenti. Nature, Lond. 214, 609.

DE KLERK, H. C. \& CoETZEe, J. N. (196I). Antibiotics among Lactobacilli. Nature, Lond. 192, 340.

De Man, J. C., Rogosa, M. \& Sharpe, M. E. (1960). A medium for the cultivation of Lactobacilli. J. appl. Bact. 23, 130.

Dent, C. E. (1947). The amino-aciduria in Fanconi syndrome. A study making extensive use of techniques based on paper partition chromatography. Biochem. J. 4I, 240.

DisCHE, Z. \& BORENFREUND, E. (1957). A new colour reaction for the determination of aldopentose in presence of other saccharides. Biochim. biophys. Acta 23, 639.

FredericQ, P. (1948). Actions antibiotiques réciproques chez les Enterobacteriaceae. Rev. Belge Pathol. Med. Exp. 29 (Suppl. 4), I.

Goebel, W. F. \& BARRY, G. T. (1958). Colicine K. II. The preparation and properties of a substance having colicine K activity. J. Exp. Med. 107, 185.

Gomori, G. (1942). A modification of the colorimetric phosphorus determination for use with the photo-electric colorimeter. J. lab. clin. Med. 27, 955.

Hamon, Y. (1964). Les bactériocines. Annls Inst. Pasteur, Paris, Suppl. 5, 18.

Hinsdill, R. D. \& Goebel, W. F. (1964). The chemical nature of bacteriocins. Annls Inst. Pasteur, Paris, Suppl. 5, 54.

HollaND, I. B. (196I). The purification and properties of megacin, a bacteriocin from Bacillus megaterium. Biochem. J. 78, 641.

Homma, J. Y. \& Suzuki, N. (1964). 'Cell-wall protein A' of Pseudomonas aeruginosa and its relationship to 'original endotoxin protein'. J. Bact. 87, 630.

Hutton, J. J. \& Goebel, W. F. (196I). Colicine V. Proc. natn. Acad. Sci., U.S.A. 47, 1498.

Hutton, J. J. \& Goebel, W. F. (1962). The isolation of colicine V and a study of its immunological properties. J. gen. Physiol. 45 (suppl.), 125.

IKaWA, M. \& SNell, E. (1960). Cell wall composition of lactic acid bacteria. J. biol. Chem. 235, I 376.

KeEne, J. H. (1966). Preparation and chemical properties of colicine I. Can. J. Microbiol. 12, 425.

Knox, K. W. \& Hall, E. A. (1965). The linkage between the polysaccharide and mucopeptide components of the cell wall of Lactobacillus casei. Biochem. J. 96, 302.

Leggett BaIley, J. (1962). Techniques in Protein Chemistry. London: Elsevier Publishing Company. 
LOWry, O. H., Rosebrovgh, N. J., FARR, A. L. \& Randall, R. J. (195I). Protein measurement with the Folin phenol reagent. J. biol. Chem. 193, 265.

MARE, I. J., CoETZEE, J. N. \& DE KLERK, H. C. (1964). Agar electrophoresis of colicines with an Alcaligenes faecalis indicator strain. Nature, Lond. 202, 213.

MUKHERJEE, S. \& SHRIVASTAVA, H. C. (1952). Improved spray reagent for the detection of sugars. Nature, Lond. 169, 330.

NÜSKE, R., HösEL, H., VENNER, H. \& ZINNER, H. (1957). Über ein Colicin aus Escherichia coli SG 7 IO. Biochem. Z. 329, 346.

PARTRIDGe, S. M. (1948). Filter-paper partition chromatography of sugars. Biochem. J. 42, 238.

ReEves, P. (1965). The bacteriocins. Bact. Rev. 29, 24.

ReEVES, P. R. (1963). Preparation of a substance having colicin F activity from Escherichia coli C.A. 42. Aust. J. exp. Biol. 4I, 163.

Salton, M. R. J. (1953). Studies of the bacterial cell wall. IV. The composition of the cell walls of some Gram-positive and Gram-negative bacteria. Biochim. biophys. Acta 10, 512.

Scotr, T. A. \& MrLVIN, E. H. (1953). Determination of dextran with anthrone. Analyt Chem. 25, 1656.

TiseluUs, A., HJeRTén, S. \& LeVIN, O. (1956). Protein chromatography on calcium phosphate columns. Arch. Biochem. Biophys. 65, 132.

WeIBULL, C. \& BERGSTRÖM, L. (1958). The chemical nature of the cytoplasmic membrane and cell wall of Bacillus megaterium, strain M. Biochim. biophys. Acta 30, 340. 